\title{
ЧОМУ БАГАТО УКРАЇНСЬКИХ МАТЕМАТИКІВ НЕ ПОЇДУТЬ ДО РОСІЇ НА МІЖНАРОДНИЙ КОНГРЕС МАТЕМАТИКІВ
}

У 2014 році в Україні вибухнула революція у відповідь на дії кримінального президента Януковича. Росія відреагувала анексією частини української території та розпочала війну на сході України. Все це робилося водночас із поширенням брехні про природу Революції Гідності та про неучасть російських військових у війні. Світ побачив дії Росії такими, якими вони були: порушенням міжнародного права та спробою перешкодити українцям як нації обирати своє майбутнє.

Війна Росії в Україні забрала вже понад 13000 життів і змусила понад 2000000 людей покинути свої домівки. Попри те, що ця війна зникла з міжнародних новин, обстріли тривають, а кількість жертв зростає щотижня. Вона виснажила українську економіку і завдала величезного удару по українській науці. Переміщені університети, поламані кар'єри науковців, припинена співпраця та розірвані наукові зв'язки. Наших колег у Криму переслідують за опір режиму Путіна.

В останні роки багато хто з нас почувався незручно, відхиляючи запрошення на наукові конференції в Росії. Яке відношення мають їхні організатори до війни? Мабуть, жодного. Однак разом із мільйонами інших українців ми не можемо ступити на російську землю починаючи з 2014 року.

Уявіть собі, якого шоку зазнали українські математики, коли у 2018 році Міжнародна математична спілка (IMU) надала Росії честь провести наступний Міжнародний конгрес математиків (ICM). Російський уряд інвестував значні ресурси, щоби виграти змагання із Францією за право проведення конгресу. Важливі міжнародні події, зокрема такі, як конгрес, легітимізують режими із кров'ю на руках. Ці режими зловтішаються з того, що ми готові прийняти їхні гроші, попри наше моральне засудження таких режимів. Високопоставлений російський урядовець Аркадій Дворкович особисто брав участь у боротьбі за проведення конгресу в Росії. Виконавчий оргкомітет конгресу очолює віце-прем'єр-міністр Дмитро Чернишенко. Серед офіційних організаторів є також високопосадовець ФСБ (колишнього КДБ) Дмитро Деревяшкін та генерал-майор російської національної гвардії Олексій Зінін. У світлі цих фактів не виглядає неймовірним те, що організація конгресу та планування війни з Україною здійснюються із сусідніх офісів.

26 лютого 2021 р. виконавчий комітет IMU опублікував заяву, в якій він підкреслив свою повну байдужість до морального аспекту прийняття рішень: „IMU, а також Міжнародна наукова рада (ISC), до складу якої входить IMU, виступають проти бойкотів наукових подій та всіх спроб пов'язати наукову діяльність з політичними та суспільними питаннями, оскільки бойкоти шкодять усьому згаданому вище". Багато хто з нас живе у високорозвиненому суспільстві, яке піклується про такі речі, як чесна торгівля кавою, або щоб продукти, які ми використовуємо, не виготовлялись із залученням дитячої праці. Тож чому IMU, яка має пред(C) О. АНТОНЮК, Т. БАНАХ, В. БЕККЕРТ ТА ІН., 2021

ISSN 1027-3190. Укр. мат. журн., 2021, m. 73, № 10 
ставляти всіх нас, залишається такою байдужою до моральних питань? Врахування основних прав людини не можна назвати „політикою” і відкинути лише тому, що це складно. Ми знаємо, що у світі існують конфлікти, ставлення до яких роз'єднують нашу спільноту. Чи означає це, що ми не повинні виносити моральні судження тоді, коли вони є очевидними? Росія анексувала частину незалежної європейської країни, чого не траплялося в Європі з часів першої половини минулого століття. Чи це неоднозначно? Чому б не потурбуватися про численні інші порушення прав людини, які здійснює Росія, такі як придушення свободи слова, політичні вбивства, переслідування ЛГБТ-спільноти? Чи IMU хоче бачити нас відстороненими машинами, які лише продукують теореми?

В історії IMU вже траплялися випадки, коли політичні події було взято до уваги. У квітні 1982 р. виконавчий комітет IMU ухвалив рішення про скасування ICM у Варшаві через запровадження воєнного стану та жорстоке придушення руху „Солідарність”. Сьогоднішня IMU вдає, що конгрес стосується лише математики, проте приблизно з 2002 року вона цілком охоче надає можливості самореклами політичним лідерам приймаючих країн. Багато кого з цих лідерів пізніше було звинувачено у корупції, деякі відбувають термін у в'язниці. Однак ніколи до 2022 року IMU не виявляла такої готовності потиснути руку, политу свіжою кров'ю. Якщо Путін забажає особисто вручити медалі Філдса, чи матиме IMU сміливість сказати „ні”? Ми в це не віримо. Керівництво IMU навіть не наважилося надіслати вимогу до Російського уряду звільнити нашого несправедливо ув'язненого колегу Азата Міфтахова.

А як щодо російських математиків? Ми цінуємо і поважаємо наших колег з Росії. Деякі 3 них виявили справжню мужність у протистоянні режиму Путіна. Однак проведення конгресу у своїй країні не є фундаментальним правом людини, але не бути вбитим російськими мінометами таким правом $€$.

Пишучи ці рядки, ми певною мірою почуваємо себе як Давид, який протистоїть Голіафу. У нас немає ресурсів багатої на нафту країни, щоб роздавати їх. Ми відстоюємо те, що вважаємо правильним. Моральна байдужість IMU має закінчитись, і ми закликаємо всіх, хто погоджується з нами, приєднатися до бойкоту ICM-2022.

О. Антонюк, Т. Банах, В. Беккерт, О. Безущак, Л. Вайнерман та ще 50 осіб (повний перелік див. за посиланням http://www.icm2022boycott.org/ukrainians) 